\title{
Implementation of Accrual-Based Government Accounting Standards in Indonesia: A Review of Organizational Factors
}

\author{
Vania Talitha \& Khoirul Aswar \\ Universitas Pembangunan Nasional Veteran Jakarta, Indonesia \\ khoirulaswar@upnvj.ac.id
}

\begin{abstract}
The purpose of this quantitative research is to test and prove empirically the effect of applying accrual-based accounting standards in Indonesia. The population in this study is the head of the financial subdivision and the financial staff of the regional government organizational unit in the DKI Jakarta province. The study used the random sampling method and managed to collect 84 respondents. Structural Equation Modeling (SEM) is used in this study as a data analysis test tool using Smart PLS software version 3.0. The results show that the quality of human resources and organizational commitment has a significant effect on the application of accrual-based accounting standards in Indonesia. Meanwhile, training and organization culture does not have a significant influence on the implementation of accrual-based accounting standards in Indonesia. The contribution for local government to improve their performance in reporting local government financial statements (LKPD) and assess their conformity with accounting standards in accordance with PP No. 71 of 2010 and ensure that the adoption of accrual-based accounting standards has been thoroughly established in local governments.
\end{abstract}

Keywords: Quality of Human Capital, Training, Organization Commitment, Organization Culture Organization.

\section{Introduction}

The public sector's use of the cash basis accounting system has been criticized since it does not offer information on costs related to institutional activities. With the presence of the accrual system, public entities are able to manage costs more rationally and public services can be maximized (Kusuma \& Fuad, 2013). The entity seeks to adopt the principles of New Public Management (NPM) which are useful for promoting accountability and transparency of the financial management system. In accordance with accrual-based accounting, this system is used to measure components of financial position. Aswar and Saidin (2018), NPM is part of management science which states that the existing management in private sector entities is better in practice. The OECD (Organization for Economic Co-Operation and Development) was formed to build the principles of New Public Management that were useful in increasing transparency and accountability in 1970. Aswar (2019) the NPM principle aims to ensure that the information disclosed in financial statements can be accounted for, relevant and credible in decision-making. Report on budget implementation on a basis that is in accordance with the APBD. Indonesia is divided into 34 provinces and 514 regencies/cities. Indonesia has implemented the accrual basis accounting system in 24 provinces and 300 districts/cities, according to the 2020 IHPS Semester 1 figure from the 2015-2019 National Medium-Term Development Plan.

According to Leksono and Haryanto's (2017) financial statements, the average value of local governments using accrual-based government accounting standards is 69.55 percent. Semarang City Government and Semarang District Government are the two levels of government in Semarang. Banyumas 72.02\%, 69.64\%, District Government. Banyuwangi 71.43\%, Tangerang City Government 68.90\%, District Government. Temanggung 69.94\%, District Government. Jepara 68.79\%, District Government. Pandeglang 76.83\%. It is concluded that Pontianak City is the local government that has the lowest disclosure value of $58.82 \%$. Then the District Government. Padeglang is the local government that has the highest value with a disclosure of $76.83 \%$. The application of the accrual-based government accounting system has many challenges. According to data from the Semester Examination Results Summary (IHPS) I 2019 records are related to the AccrualBased Agency Accounting System (SAIBA). The preparation of capital expenditure realization is not applied in the SIMAK BMN application related to the input of assets in the fiscal year, the amount and type of assets are the same in the Central and regional DIPA. Due to the use of journals, this causes an indication of assets that have not been nullified and have not been inputted amounting to Rp. 6.69 trillion.

Then, the opinion on the 2018 LKTBI stated that BI had made inaccurate records related to BI's income recording related to the administrative sanctions for Export Proceeds (DHE) which still applied on a cash 
basis. BI's income from administrative sanctions for Export Proceeds (DHE) has not been recorded and this claim has not been paid since 2012. Based on IHPS 1 of 2018, the obligation to pay Non-Bank Funds Transfer Reports (LTDBB) has not been recognized as receivables but is recognized and recorded when cash is received. In addition, there is a report that was found by BPK from OJK in 2018 which stated that prepaid expenses were not utilized for building rent. According to Simanjuntak (2010) and Najati, Pituriningsih, and Animah (2016), the government faces major challenges in adopting accrual-based accounting standards, namely good Human Resources (HR), Information technology, accounting systems, leadership commitment, agility to changes, as well as opinions given by the Supreme Audit Agency. The work unit has a role as the main driver in maximizing the application of the accrual-based government accounting system. Things that affect the work unit, starting from the quality of human resources, the training provided educational background, and organizational commitment. Ardiansyah (2013) in Ajhar, Akram, and Pituriningsih (2015) the quality of human resources (HR) is one of the many factors that influence the government's capability in applying accrual-based accounting standards. Human resource quality is a crucial factor in the organization as well as a driving force. Training, strong communication, a good educational background, and corporate culture are all required to maximize the quality of human resources (Ouda, 2008).

So that the government in Indonesia must manage human resources in the field of government accounting well. Hamalik (2007) training is a series of processes aimed at the workforce that are executed by experts/professionals in their field. Training is useful in improving the ability and performance of the workforce. An organization's effectiveness and production are projected to rise as a result of training. Some discovered that training attempts to increase individual skills and that training can influence the success of accrual accounting application and execution. An adequate training program has a considerable impact on the use of the accrual accounting system (Aswar \& Saidin, 2018). The use of accrual-based accounting necessitates extensive training (Najati et al., 2016). If accrual accounting training is more adequate, Jonathan, Aswar, and Ermawati (2020) believe that increasing the use of accrual-based accounting standards will be encouraged. Sinambela (2018) organizations can grow rapidly if the organization has professional, committed, quality and integrity human resources. In Irfani, Pituriningsih, and Husnan (2020), a strong commitment can realize the maximum application of the accrual basis. Because it takes time for preparation and collaboration of all entity units, from accounting entities, treasury units, reporting entities, and accounting standard-setting units. If the organizational commitment is high, the implementation of New Public Management will be ideal, and the accrual-based accounting system will be implemented successfully. Organizational commitment is a type of motivation from inside the workforce to do something to support the organization's success in meeting its objectives (Aswar, 2019).

Azman (2015) the government's readiness to implement the accrual-based accounting system depends on organizational commitment. Chatab (2007) states that $74 \%$ of all organizations have failed due to not being aware of the importance of a good organizational culture. Hidayah and Zarkasyi (2017), Hofstede (1990) organization culture is characterized by prioritizing the interests of self-commitment to things that are more important than self-interest. The sample was chosen to represent the overall level of application of the accrual-based government accounting system. Culture is said to be the glue that holds organizations together by setting standards for what workers can and cannot do. Robbins (2003) organization culture forms a mechanism in giving meaning that can shape the attitude of each individual (Jonathan, Aswar \& Ermawati 2020). This study adds to the literature on human resource quality, training, organizational commitment, organizational culture, and the adoption of accrual-based accounting standards in accordance with previous research recommendations (Nasution, Erlina \& Sari, 2016; Ajhar, Akram \& Pituriningsih, 2015; Najati et al., 2016; Seda \& Christiaens 2017). Najati et al. (2016) employed the training, organization culture, and the use of accrual accounting instead of organizational commitment, which is linked to HR quality. Then, in a study by Basri et al. (2016), they used organizational commitment, human resource quality, information technology usefulness, and government readiness to implement accrual-based accounting systems without considering correlations like training and organizational culture. The goal of this research is to look into and verify the impact of using accrual-based government accounting standards in Indonesia. 


\section{Literature Review and Hypothesis Development}

Institutional Theory: Organizations are formed by the institutional environment around everyone. The ideas that these individuals have that have influence are institutionalized and are considered legitimate values of the organization. Scapens (2007) in Hidayah (2017) states that the organization adopts a system, structure, or procedure related to the environmental culture in the organization. DiMaggio and Powell (1983) in Aswar (2019) have three mechanisms that cause institutional isomorphism, external pressures that shape organizations as coercive isomorphism, normative isomorphism, and mimetic isomorphism. Coercive isomorphism is when an organization decides to adopt something because of pressures from the wider community or other entities to fulfill its expectations.

Implementation of Accrual Accounting: According to Jonathan et al. (2020), organizational success is influenced by the organization's ability to attain and retain legitimacy in its environment, according to the new institutional theory. Various studies in public sector accounting reform in developed and developing nations have employed institutional theory. Institutional theory has been utilized as a conceptual framework in previous research on public sector accounting to prove numerous aspects that influence the use of accrualbased accounting rules (Mbelwa, Adhikari \& Shahadat, 2019; Seda \& Christiaens, 2017; Nor- Aziah and Scapens, 2007; Jonathan, Aswar \& Ermawati, 2020; Adhikari \& Nesbakk, 2016; Aswar \& Saidin, 2018a; Aswar and Saidin, 2018b). Based on the previous study, many studies that focus on the quality of HR, Nasution et al. (2016) consider HR, supporting facilities, incentives, and organizational commitment to see the effect of accrual-based SAP implementation. Respondents in this study reached 102 respondents from the finance and treasury departments taken from 34 SKPD of North Sumatra Province. The results of this study indicate that the quality of human resources and incentives has a positive significance but supporting facilities have a negative significant effect. SKPD commitment is able to moderate to strengthen or weaken each variable. Jonathan et al. (2020) used moderating variables such as training, communication, educational background, and organizational culture to examine the adoption of accruals in the Indonesian government. This study was carried out in Bekasi City, with questionnaires distributed to 44 regional organizations.

According to the findings, training and communication have a substantial impact on the implementation of accrual-based accounting, although educational background has no such impact. The ability of organizational culture to control the relevant factors has been demonstrated. Irfani et al. (2020) examined the effect of organizational commitment, accounting training, use of the SAIBA application, and employee education in the finance department on the success rate of implementing the accrual accounting system in agencies. Multiple linear regression analysis was applied in this study. The work unit of the BPN Regional Office of West Nusa Tenggara Province was chosen in executing this research with a total of 63 respondents. The results of this study state that the New Public Management theory strengthens the variables related to the use of the SAIBA application, education of employees in the finance department, organizational commitment, and accounting training to correlate with the success of implementing the accrual accounting system in the scope of the agency. Survey-descriptive research by Hidayah and Zakarsyi (2017) analyzes the inter-role of culture, management competence, and HR in the effectiveness of adopting the accrual accounting system and the impact of the quality of accounting information. The aim is to test the validity of the questionnaire by using the Smart PLS software application with Cronbach's alpha. The findings revealed that HR management competency had a substantial impact on the efficiency of accrual accounting implementation, while culture had no impact on the quality of accounting data.

Conceptual Framework and Hypotheses: The hypothesis in this study is produced based on the components that influence the adoption of accrual-based government accounting standards following the creation of each hypothesis:

The Influence of HR Quality on the Implementation of Accrual-Based Government Accounting Standards in Local Governments: Based on the context of institutional theory, this is in line with the institutional theory of normative isomorphism, which means that improving the quality of human resources is necessary for professional demands. According to Robbins (2003), the ability of human resources is as an individual's ability to do tasks at work. Entities must manage HR as much as possible so that the contribution of each individual can affect the achievement of organizational goals. The significance of HR quality on the 
implementation of accrual-based accounting standards (Basri, Fahlevi, \& Soraya, 2016; Hidayah \& Zakarsyi, 2017; Safitri, 2017).

H1: The quality of resources has a significant effect on the implementation of accrual accounting standards.

The Effect of Training on the Implementation of Accrual-Based Government Accounting Standards in Local Governments: In the context of institutional theory, training is related to normative isomorphism institutional theory, which means that training is used as a medium of learning and skill improvement due to professional guidance. Training provides an opportunity for each individual to prepare and equip themselves in the form of insight and skills needed in accordance with the work carried out (Mondy, 2008). A previous study stated that there was significance between the training on the implementation of accrual-based accounting standards (Dianto \& Aswar, 2020; Aswar \& Saidin, 2018; Jonathan, Aswar \& Ermawati, 2020). H2: Training has a significant effect on the implementation of accrual accounting standards.

The Effect of Organizational Commitment on the Implementation of Accrual-Based Government Accounting Standards in Local Governments: According to the context of institutional theory, organizational commitment is related to the institutional theory of coercive isomorphism which is described by the government as being required to decide to adopt something because of pressures from other entities to fulfill its expectations. Fuad and Akhmadi (2018) explained that the challenge in the process of implementing Government Regulation no. 71 of 2010 one of which is due to the lack of commitment in local government organizations in adopting the changes so that the government is not ready to face the changes. Mbelwa, Adhikari \& Shahadat (2019) positively support organizational commitment in implementing accounting standards on an accrual basis in Tanzania. This research is also supported in Indonesia (Safitri, 2017; Putra \& Ariyanto, 2015; Irfani, Pituriningsih \& Husnan, 2020).

H3: Organizational commitment has a significant effect on the implementation of accrual accounting standards.

The Influence of Organizational Culture on the Implementation of Accrual-Based Government Accounting Standards in Local Governments: Organizational culture is related to normative isomorphism institutional theory in the setting of institutional theory; specifically the application of organizational culture is a requirement because it is a professional need. In Najati, Pituriningsih, and Animah (2016), organizational culture drives people to meet change's challenges since culture has an impact on their behavior in the workplace. The use of accrual-based government accounting standards is maximized when there is a healthy organizational culture and each employee's supporting conduct in coping with changes. A previous study has found that the use of accrual-based accounting rules is influenced by organizational culture (Najati et al., 2016; Aswar \& Saidin, 2018; Jonathan et al., 2020).

H4: Organizational culture has a significant effect on the implementation of accrual accounting standards.

Figure 1: Research Framework

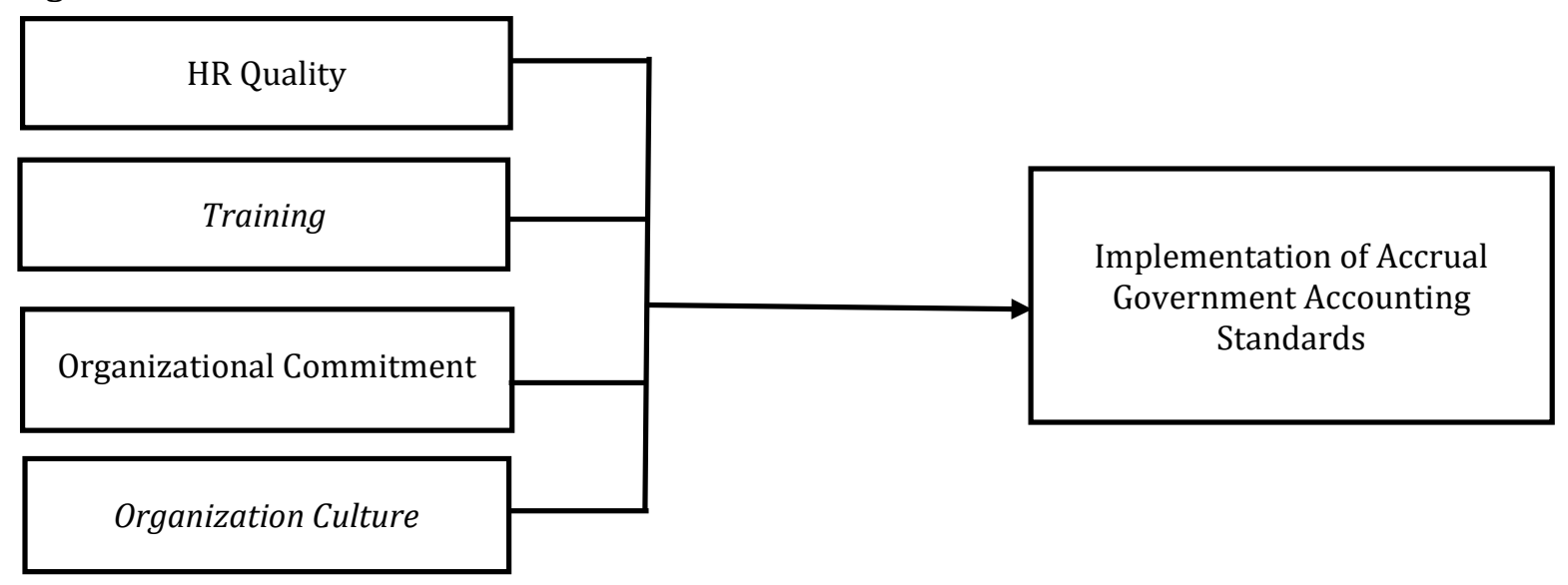




\section{Research Methodology}

The population in this study is a local government organizational unit in the DKI Jakarta area. Regional government organizational units in the DKI Jakarta area were selected based on the random sampling method. Then local government organizations in the DKI Jakarta area have a different structural arrangement from other urban areas. The study collects samples based on predetermined criteria, namely the reporting entity and the recording entity where the individual units are the head of the finance subdivision and finance staff. In total 78 regional organizational units in the DKI Jakarta province are used as samples in this study. The sample was chosen to represent the overall level of application of the accrual-based government accounting system. The total sample of this research is 156 samples. The unit of analysis in this study is the individual in charge of recording and compiling OPD financial reports in the DKI Jakarta province. Then the data collection for this research has been carried out through the distribution of questionnaires which are distributed directly to each unit of local government organizations. The data collected is in the form of a questionnaire filled out by 2 people, namely the head of the finance sub-section and the finance staff. The method in this research is quantitative - primary. Literature research is carried out by collecting information related to the variables contained in this study, namely by understanding references in the form of accounting journals, books, and related supporting sites. Each of these research variables has its measurements adopted from previous studies. Following are the indicators used by each variable:

Table 1: Variable Measurement

\begin{tabular}{|c|c|c|}
\hline Variable & Measurement & Source \\
\hline $\begin{array}{l}\text { Application of Accrual-Based } \\
\text { Government Accounting } \\
\text { Standards in Indonesia }\end{array}$ & $\begin{array}{l}\text { Revenue recognition, expense recognition, asset } \\
\text { recognition, debt recognition, and equity recognition }\end{array}$ & $\begin{array}{l}\text { Aswar and Saidin } \\
\text { (2018) }\end{array}$ \\
\hline HR Quality & $\begin{array}{l}\text { The variable quality of human resources is measured by } \\
\text { the level of education, experience, training, accounting } \\
\text { understanding, and professionalism. }\end{array}$ & $\begin{array}{l}\text { Nasution, Erlina } \\
\text { and Sari (2016). }\end{array}$ \\
\hline Training & $\begin{array}{l}\text { Training is measured based on the dimensions of the } \\
\text { training program and training competence. }\end{array}$ & $\begin{array}{l}\text { Aswar and Saidin } \\
\text { (2018) }\end{array}$ \\
\hline Organizational Commitment & $\begin{array}{l}\text { Organizational commitment is measured based on } \\
\text { organizational commitment in adopting accrual } \\
\text { accounting and the level of accuracy and reliability of the } \\
\text { resulting financial statements. }\end{array}$ & $\begin{array}{lr}\text { Basri, } & \text { Fahlevi, } \\
\text { and } & \text { Soraya } \\
(2016) & \end{array}$ \\
\hline Organization Culture & $\begin{array}{l}\text { Organizational Culture is measured by the openness and } \\
\text { willingness of employees to support collaboration and } \\
\text { adoption of accrual-based accounting, the enthusiasm of } \\
\text { employees in self-development, and respect for } \\
\text { employees by superiors. }\end{array}$ & $\begin{array}{l}\text { Aswar and Saidin } \\
\text { (2018) }\end{array}$ \\
\hline
\end{tabular}

\section{Results and Discussion}

The study's participants include 78 local government entities in the DKI Jakarta area. The sample was chosen using a random sampling procedure. Furthermore, this study used the SmartPLS version 3.0 tools to conduct data analysis utilizing the Structural Equation Model (SEM). Table 2 shows the descriptive statistics of the data.

Table 2: Descriptive Statistics of Data

\begin{tabular}{llcl}
\hline Variable & Total question items & Mean & Std. Deviation \\
\hline Application of Accrual-Based Accounting Standards & 5 & 3,86 & 0,108 \\
HR Quality & 4 & 3,82 & 0,339 \\
Training & 8 & 4,10 & 0,271 \\
Organizational Commitment & 6 & 3,86 & 0,373 \\
Organization culture & 7 & 4,29 & 0,062 \\
\hline
\end{tabular}


The mean variable for the use of accrual-based accounting standards is 3.86 , with a standard deviation of 0.108. According to the descriptive statistics in table 2, the mean variable for accrual-based accounting standards implementation is 3.86 , with a standard deviation of 0.108 . The quality of human resources has a mean of 3.82 and a standard deviation of 0.339. After then, the training's mean is 4.10, with a standard deviation of 0.271 . Furthermore, organizational commitment has a mean of 3.86 and a standard deviation of 0.373 . The organization's culture has a mean of 4.29 and a standard deviation of 0.062 .

Table 3: Reliability Test and Convergent Validity Test

\begin{tabular}{llll}
\hline Variable & Average Varian Extracted (AVE) & Composite Reliability & Cronbach's Alpha \\
\hline AA & 0,666 & 0,909 & 0,874 \\
SDM & 0,548 & 0,820 & 0,710 \\
LAT & 0,581 & 0,913 & 0,899 \\
KO & 0,521 & 0,764 & 0,562 \\
BO & 0,589 & 0,909 & 0,884 \\
\hline
\end{tabular}

In table 3, it is stated that the minimal value for the reliability test consisting of the results of the composite reliability test and Cronbach's alpha, as defined by Hair et al. (2014), is 0.7 for standard composite reliability and 0.6 for Cronbach's alpha. According to the findings of the tests, the organizational commitment has the lowest Cronbach's Alpha value of 0.562, indicating that this variable is near to a reliable number. The variables in this study show strong reliability in each construct, it can be concluded. Convergent validity measures the extent to which each item that reflects a convergent construct differs from that of an item that measures a different construct. The findings of the average variance extracted (AVE) with a minimum value of 0.50 reveal the convergent validity test. The results of the tests carried out on the variables used in this study were all displayed values above 0.50 . So, it can be concluded that all variables are declared valid.

Table 4: Discriminant Validity Test

\begin{tabular}{llllll}
\hline Variable & AA & LAT & SDM & KO & BO \\
\hline AA & 0,816 & 0,365 & 0,408 & 0,450 & 0,432 \\
LAT & & 0,763 & 0,617 & 0,255 & 0,527 \\
SDM & & 0,740 & 0,284 & 0,634 \\
KO & & & 0,722 & 0,433 \\
BO & & & & 0,767 \\
\hline
\end{tabular}

The construct in each variable has a discriminant validity value of greater than 0.6 according to the FornellLacker Criterion table. Applying accrual-based accounting standards (AA) are 0.816, training (LAT) are 0.763, HR quality (HR) is 0.740 , organizational commitment (KO) is 0.722 , and organization culture (BO) is 0.767 . It was concluded that all constructs in each variable were declared valid.

Table 5: Testing PLS Path Algorithm and Bootstrapping

\begin{tabular}{llll}
\hline Variable & Path Coefficient (Original Sample) & T Statistics & P Values \\
\hline SDM -> AA & 0,221 & 1,998 & 0,046 \\
LAT -> AA & 0,043 & 0,344 & 0,731 \\
KO -> AA & 0,316 & 3,007 & 0,003 \\
BO -> IAA & 0,152 & 1,005 & 0,316 \\
\hline
\end{tabular}

The quality of human resources (HR) has a positive relationship with the application of accrual-based accounting, procedures, as shown in table 5 , with a constant value of 0.221 . The quality of human resources has improved by 0.221 as a result of the adoption of accrual-based accounting procedures, while the other factors remain the same. As a result, the implementation of accrual-based accounting standards will expand as the value of human resources improves. T-count $>t$ table of $1.998>1.99045$ and a significant value of 0.0460 .05 demonstrating that the quality of human resources has a substantial effect on the application of 
accrual-based accounting standards (AA), then Ha1 is acceptable. This is consistent with Basri, Fahlevi, and Soraya (2016), who investigated the readiness to adopt the accrual accounting system in government agencies in Banda Aceh and discovered that the quality of human resources had a positive and significant impact on the readiness to adopt the accrual accounting system in government agencies. Through a study conducted at SKPD Banten, Hidayah and Zakarsyi (2017) conclude that the quality of human resources has a favorable and significant impact on the success of accrual accounting implementation. The training path coefficient (LAT) has a value of 0.043 . Other variables stay unchanged, but the training has increased by 0.043 , indicating that the use of accrual-based accounting standards has a positive relationship.

If a result, as the training value rises, the use of accrual-based accounting rules will rise as well. When t-count $>t$ table of $0.344>1.99045$ and a significant value of 0.7310 .05 in the association between training (LAT) and the application of accrual-based accounting standards (AA) reveals a significant value of 0.7310 .05 , Ha2 is rejected. This supports the findings of Irfani, Pituriningsih, and Husnan (2020), which conducted research at the NTB Province BPN regional office on the successful implementation of an accrual-based agency accounting system and discovered that no training program had a positive and significant impact on the system's success. Then, according to Widianti, et al. (2016), the training provided has no beneficial or substantial influence on the application of accrual accounting in the government sector in the Tegal Regency government SKPD. However, Dianto and Aswar (2020), Aswar and Saidin (2018), Jonathan et al. (2020). This demonstrates that the use of sufficient user training given by third parties in the form of vendors or external consultants is still debatable. Individuals do not have full access to learning and self-development due to inefficient implementation of training programs arranged by vendors or adequate external consultants supplied to users, notably in the financial sector. Training for accountants has little effect on the implementation of accrual-based accounting standards being maximized. Organizational commitment (KO) has a path coefficient of 0.316 .

Other variables stay constant, but the organizational commitment has increased by 0.316 , indicating that the use of accrual-based accounting standards has a positive association. If a result, as the value of organizational commitment rises, the use of accrual-based accounting rules will rise as well. Organizational commitment (KO) to the application of accrual-based accounting standards (AA) has a significant value of 0.0030 .05 and a value of $t$ count $>t$ table of $3.007>1.99045$, implying that the use of accrual-based accounting standards is influenced by organizational commitment. Adhikari \& Shahadat (2019) support organizational commitment in providing positive support in applying accounting standards on an accrual basis in Tanzania, which is in line with Mbelwa's research. This demonstrates that the type of organizational commitment that is created might increase accrual accounting implementation. In addition, In Bengkalis Regency SKPD, Safitri (2017) did a study that supports organizational commitment in influencing accrual-based government accounting standards. Organizational commitment has a positive impact on the application of accrual-based government accounting regulations, according to Putra and Ariyanto (2015). Furthermore, the organization culture (BO) has a path coefficient of 0.152 . This demonstrates that the application of accrual-based accounting standards is influenced by organizational culture. As a result, the employment of accrual-based accounting procedures will increase in tandem with the value of the organization's culture.

Ha4 is rejected when the impact of organizational culture (BO) on the adoption of accrual-based accounting standards (AA) is t count $>t$ table of $1.005>1.99045$ with a significant value of 0.3160 .05 . These findings imply that organizational culture has no influence on the adoption of accrual-based accounting. This contradicts the institutional theory of normative isomorphism, which states that organizational culture acts as an individual's enthusiasm for self-development and supports the application of accrual-based accounting standards as the professional demands of entities in adopting a system based on accrual-based accounting standards. This is in line with the findings of Hidayah and Zakarsyi (2017), which discovered that organizational culture had no impact on the success of accrual accounting implementation. However, it contradicts the findings of Najati, Pituriningsih, and Animah (2016), Aswar and Saidin (2018), and Jonathan et al. (2020). These findings suggest that, in addition to formal training, individual growth possibilities provided by the organization, such as job diversity and rotation, do not receive learning based on direct experience, particularly in the financial sector. This shows that the lack of experience and learning that employees gain due to a lack of job rotation and variety of work assignments does not necessarily influence the adoption of accrual-based accounting rules in an environment with a healthy organizational culture. 


\section{Conclusion and Recommendations}

The purpose of this study is to investigate and demonstrate the impact of the independent factors of human resource quality, training, organizational commitment, and organizational culture on the accrual-based accounting standards adoption in the DKI Jakarta Province. The quality of human resources has a positive and significant effect on the application of accrual-based accounting standards. This shows that the good quality of human resources owned by recording actors and reporting financial statements of local government organizational units can improve and facilitate the implementation of accrual-based accounting standards. Training has no positive and significant effect on the application of accrual-based accounting standards. This shows that respondents who have participated in training activities while they are tied to local government organizational units do not affect the level of application of accrual-based accounting standards. Organizational Commitment has a positive and significant effect on the application of accrual-based accounting standards. This indicates that good organizational commitment can improve and facilitate the application of accrual-based accounting standards. This result is also due to the existence of a strong individual desire to provide the best results in each of their performances which can improve the application of accrual-based accounting standards in the regional government organizational unit. Organizational culture has no positive and significant effect on the application of accrual-based accounting standards. This indicates that the organization's culture is formed from a government organizational unit.

Some limitations of researchers in carrying out this research are the number of questionnaires that have not been returned by respondents is quite a lot of 72 questionnaires. This is due to the Emergency PPKM and the high exposure to Covid-19 in DKI Jakarta. Public entities, which are largely exposed to Covid-19, have decided to lock down to stymie the licensing process. Respondents who are frequently out of the office for assignments or who work from home (WFH) and who are self-isolating are hampered by the current pandemic; the entity hasn't had time to process research submissions, and respondents haven't had time to complete questionnaires distributed by researchers. Because the research was limited to the DKI Jakarta Province's regional administration, it was unable to provide a more comprehensive picture or extrapolate to the entire Indonesian government's application of accrual accounting. Researchers should also collect study data using interview methodologies to dive further into the application of accrual-based accounting standards and get more answers. It is envisaged that scholars will broaden their research reach outside the DKI Jakarta Province's regional government organizational entities. The addition and variation of other variables that can affect the application of accrual-based accounting standards, such as facility support and the use of accrual-based agency accounting system applications for developing research are among the recommendations for future research based on the findings of this study.

\section{References}

Seda, S. S. \& Christiaens, J. (2017). Why do some municipalities apply accrual-based rules more than others? Evidence from Turkey. Technical University of Liberec, Czech Republic, 3(20), 189-206.

Adhikari, P. \& Gårseth-Nesbakk, L. (2016). Implementing public sector accruals in OECD member states: major issues and challenges. Accounting Forum, 40(2), 125-142.

Ajhar, Akram Pituriningsih, E. (2015). Factors that influence the readiness of accrual-based SAP implementation and performance accountability of government agencies (empirical study on the local government of Dompu Regency). Journal of Actual Accounting, 3(1), 62-73.

Ardiansyah, A. (2013). Factors affecting the effecting the readiness of PP 71 of 2010 about government accounting standards (case study on working units in KPPN Malang's working area). FEB Student Scientific Journal, 1(1), 1-16.

Aswar, K. \& Saidin, S. Z. (2018). Accrual accounting adoption in Java Municipalities: an empirical investigation. International Journal of Business and Economic Sciences Applied Research, 11(3), 24-30.

Aswar, K. \& Saidin, S. Z. (2018). The influencing factors on the level of accrual accounting adoption: a conceptual approach. Romanian Economic and Business Review, 13(2), 30-36.

Aswar, K. (2019). Factors on the accrual accounting adoption: empirical evidence from Indonesia. International Journal of Business and Economic Sciences Applied Research, 12(3), 36-42.

Aswar, K. \& Ermawati. (2020). Adoption of accrual accounting in local government: a case study in Banten Province. EQUITY: Journal of Economics, Management, Accounting, 22(1), 62-74. 
Azman, T. (2015). Analisis komitmen organisasi, sumber daya manusia, infrastruktur serta sistem informasi dalam dalam penerapan standar akuntansi pemerintah berbasis akrual (studi kasus skpd pemerintah kabupaten kepulauan meranti). Jurnal SOROT, 10(1), 1-142.

Basri, H., Fahlevi, H. S. \& Soraya H. (2016). Determinants of government agencies readiness in adopting accrual accounting system - a study in the local agencies of the Indonesian Ministry of Religious Affairs. Publication Journal of Accounting, Finance and Auditing Studies, 2(4), 60-74.

Supreme Audit Agency of the Republic of Indonesia. (2016). Summary of Financial Audit Results Semester I 2016, 420.

Supreme Audit Agency of the Republic of Indonesia. (2018). Summary of First Semester 2018 Financial Audit Results Index. Semester 12018 Audit Results Index, 470.

Supreme Audit Agency of the Republic of Indonesia. (2019). Summary of First Semester Financial Audit Results, 426.

Chatab, N. (2007). Organization culture profile: Diagnosing Culture and Stimulating Change. Alphabet. Bandung.

Dianto, A. W. \& Aswar, K. (2020). Assessing accrual accounting implementation in Cianjur Regency: an empirical investigation. International Journal of Business and Economic Sciences Applied Research, 13(1), 7-12.

DiMaggio, P. J. \& Powell, W. W. (1983). The iron cage revisited: institutional isomorphism and collective rationality in organizational fields. American Sociological Review, 48, 147-160.

Fuad, A. F. \& Akhmadi. (2018). Pengaruh lingkungan kerja non fisik dan komitmen organisasi terhadap kinerja karyawan dengan kepuasan kerja intrinsik sebagai variabel intervening (studi kasus pada pt. paramitra gunakarya cemerlang, asia pulp and paper - sinarmas grup). Jurnal Riset Bisnis dan Manajemen Tirtayasa, 2(2), 126-145.

Hamalik, 0. (2007). Manajemen Pelatihan Ketenagakerjaan Pendekatan Terpadu Pengembangan Sumber Daya Manusia. Jakarta: Bumi Aksara

Hidayah, N. \& Zarkasyi, W. (2017). The effect of human resources management competency and the role of culture on accrual accounting implementation effectiveness and the impact on quality of accounting information. European Research Studies Journal, 20(4B), 183-199.

Hofstede, G. (1990). Measuring organizational cultures: qualitative and quantitative study across twenty cases. Administrative Science Quarterly, 35(2), 286-316.

Irfani, M., Pituriningsih E. \& Husnan, L. H. (2020). Determinan keberhasilan penerapan sistem akuntansi instansi berbasis akrual dalam penyusunan laporan keuangan pemerintah. E-Jurnal Akuntansi, 30(6), 1522-1538.

Jonathan, A. T. P., Aswar, K. \& Ermawati. (2020). Implementasi akuntansi akrual di pemerintah Indonesia: peranan budaya organisasi sebagai moderasi. Journal of Economic and Behavioral Studies, 12(4), 6772.

Kusuma, M. I. Y. \& Fuad. (2013). Analisis faktor faktor yang mempengaruhi tingkat penerapan akuntansi akrual pada pemerintah. Diponegoro Journal of Accounting, 2(3), 1.

Leksono, B. S. \& Haryanto. (2017). Evaluasi penerapan standar akuntansi pemerintahan (sap) akrual dalam penyusunan laporan keuangan tahun 2014 dan 2015 pada pemerintah daerah di indonesia. Diponegoro Journal of Accounting, 6(1), 1-7.

Mbelwa, L. H., Adhikari, P. \& Shahadat, K. (2019). Investigation of the institutional and decision-usefulness factors in the implementation of accrual accounting reforms in the public sector of Tanzania. Journal of Accounting in Emerging Economies, 9(3), 335-365.

Mondy, R. W. (2008). Manajemen SDM. Jakarta: Erlangga.

Najati, I., Pituringsih, E. \& Animah. (2016). Implementasi akuntansi berbasis akrual: pengujian determinan dan implikasinya terhadap kualitas laporan keuangan kementerian/lembaga. Jurnal Akuntansi Universitas Jember, 14(1), 1-16.

Nasution, D. A., Erlina, D. \& Sari, T. A. (2016). Analisis faktor-faktor yang mempengaruhi implementasi SAP berbasis akrual dengan komitmen SKPD sebagai variabel moderating pada pemerintah Provinsi Sumatera Utara. Jurnal Ekonom, 19(4), 175-185.

Nor-Aziah, A. K. \& Scapens, R. W. (2007). Corporatization and accounting change. Management Accounting Research, 18(2), 209-247.

Ouda, H. A. G. (2008). Towards a generic model for government sector reform: the New Zealand experience. International Journal on Governmental Financial Management, 2, 91. 
Putra, I. W. G. Y. D. \& Ariyanto, D. (2015). Faktor-faktor yang mempengaruhi penerapan standar akuntansi pemerintahan berbasis akrual. E-Jurnal Akuntansi Universitas Udayana, 13(1), 14-32.

Robbins, S. P. (2003). Perilaku Organisasi Jilid 2. Jakarta: PT. Indeks.

Safitri, D. (2017). Faktor faktor yang mempengaruhi penerapan standar akuntansi pemerintahan berbasis akrual (Studi pada skpd pemerintah kabupaten bengkalis), Jurnal Akuntansi, 5(2), 174-189.

Simanjuntak, B. H. (2010). Menyongsong era baru akuntansi pemerintahan di Indonesia. Disampaikan pada Kongres XI Ikatan Akuntan Indonesia, 1-15.

Sinambela, L. P. (2018). Manajemen Sumber Daya Manusia. Jakarta: PT Bumi Aksara.

Widianti, H., Hadiyati, S. N. \& Sulistyowati, D. (2016). Analisis faktor-faktor yang mempengaruhi implementasi akuntansi akrual pada sektor pemerintah. SENIT, 1(1), 155-162. 